\title{
PÓS-COLONIALISMO E TRADUÇÃO: UMA ANÁLISE DO ROMANCE HALF A LIFE E SUA TRADUÇÃO PARA O PORTUGUÊS
}

\author{
Mirian Ruffini ${ }^{*}$ \\ Gabriel Both Borella ${ }^{1 * *}$ \\ ${ }^{1}$ Universidade Tecnológica Federal do Paraná, Pato Branco, Paraná, Brasil
}

\begin{abstract}
Resumo
A publicação de traduções de obras literárias de cunho pós-colonial vem cada vez mais ganhando espaço no mercado editorial brasileiro. Neste artigo, busca-se a articulação entre os Estudos da Tradução e os Estudos Pós-Coloniais por meio da análise do romance pós-colonial Half a Life, de V.S. Naipaul e a sua tradução para o português brasileiro, intitulada Meia Vida. Discussões de aspectos ideológicos na tradução de textos póscoloniais e a própria escolha do que é traduzido e por quem são questões levantadas pelo texto, bem como os desafios de se traduzir textos literários pós-coloniais. Por fim, discute-se de que maneira o discurso pós-colonial da obra original é transmitido por meio da tradução, averiguando possíveis supressões ou manutenções do tom pós-colonial da obra originária na obra traduzida.

Palavras-chave: Pós-Colonial; Tradução; V.S. Naipaul; Literatura.

\section{POSTCOLONIALISM AND TRANSLATION: AN ANALYSIS OF THE NOVEL HALF A LIFE AND ITS TRANSLATION TO PORTUGUESE}

\begin{abstract}
The publication of translations of postcolonial literary works is increasingly gaining space in the Brazilian publishing market. In this article, the articulation between Translation Studies and Postcolonial Studies is
\end{abstract}

\footnotetext{
* Docente de Magistério Superior na Universidade Tecnológica Federal do Paraná, Campus Pato Branco, Departamento e Coordenação de Letras, DALET/COLET. Docente do Programa de Pós-graduação em Letras da UTFPR - Campus Pato Branco (PPGL). Doutora em Estudos da Tradução, pelo Programa de Pósgraduação em Estudos da Tradução (PGET) na Universidade Federal de Santa Catarina. É Mestre em Letras pela Universidade Estadual de Londrina (2002) e Especialista em Língua Inglesa e Literatura de Língua Inglesa pela Universidade Estadual de Londrina (1998). Atua na área de Letras, principalmente nas seguintes subáreas: Tradução Literária, Estudos de Tradução, Língua Inglesa e Literatura de Língua Inglesa, Literatura Comparada. E-mail: mruffini95@gmail.com. ORCID: https://orcid.org/0000-0002-3222-2519.

** Licenciado em Letras Português-Inglês pela Universidade Tecnológica Federal do Paraná (2015) e mestrando do Programa de Pós-Graduação em Letras da Universidade Tecnológica Federal do Paraná, campus Pato Branco, na linha de pesquisa Literatura, Sociedade e Interartes. E-mail: gabrielborella_17@hotmail.com. ORCID: https://orcid.org/0000-0002-3765-4521.
} 
sought through the analysis of the post-colonial novel Half a Life, by V.S. Naipaul, and its translation to Brazilian Portuguese, entitled Meia Vida. Discussions of ideological aspects in the translation of postcolonial texts and the very choice of what is translated and by whom are questions raised by the text, as well as the challenges of translating postcolonial literary texts. Finally, it is discussed how the postcolonial discourse of the original work is transmitted through translation, ascertaining possible suppression or maintenance of the postcolonial tone of the original work in the translated work.

Keywords: Postcolonial; Translation; V.S. Naipaul; Literature. 
Introdução

A tradução possibilita, muitas vezes, levar escritas e culturas marginalizadas ao centro de um sistema literário. Ao tratarmos de literatura, e mais especificamente da literatura pós-colonial, o conceito do cânone literário é um dos primeiros que surgem para debate, pois estamos tratando de textos literários historicamente marginalizados em culturas centrais. Even-Zohar afirma que, historicamente, a literatura canonizada se refere a determinadas obras e normas literárias que "são aceitas e legitimadas por círculos dominantes dentro de uma cultura na qual seus vistosos produtos são preservados pela comunidade para se tornarem parte de seu patrimônio histórico"1 (EVEN-ZOHAR, 1990, p. 15 , nossa tradução). Por outro lado, a literatura não-canonizada é aquela cujas obras e normas literárias são rejeitadas por esses círculos e frequentemente esquecidas pela comunidade, a não ser que mude de status.

Recentemente, textos literários de culturas minoritárias vêm ganhando cada vez mais reconhecimento por meio de traduções, prêmios literários e prestígio acadêmico. É o caso da obra do escritor trinitário de ascendência indiana Vidiadhar Surajprasad Naipaul, ${ }^{2}$ que atingiu o ápice literário ao ganhar o Prêmio Nobel de Literatura no ano de 2001. Antes mesmo dele, outros escritores de antigas colônias britânicas já haviam sido condecorados com essa honraria, como o nigeriano Wole Soyinka, em 1986 e o santa-lucense Derek Walcott, em 1992. Todos esses escritores têm em comum o fato de serem autores pós-coloniais, que trazem em suas obras as vozes e culturas periféricas, antes suprimidas pelo sistema imperialista.

O tipo de escrita produzida por esses autores citados acima, além de outros vários, é denominado literatura pós-colonial ou escrita pós-colonial (TYMOCZKO, 2002), pois trata de questionar as relações constituídas pelo colonialismo por meio da linguagem literária. O discurso do colonizado, porém, não ganha voz somente pelo intermédio da literatura, mas também a partir da publicação de uma série de obras teóricas de cunho social e antropológico que procuram analisar "o imperialismo e suas influências" (BONNICI, 1998, p. 10). Isso posto, a valorização do colonizado, dos pontos de vista literário e teórico, começa a ganhar força na década de 1970, tendo como grande marco a publicação do livro Orientalismo, do palestino Edward Said, publicado em 1978. Portanto, o discurso crítico do colonizado frente ao do colonizador, tanto na literatura quanto na teoria é chamado de pós-colonialismo. Esse termo será melhor explicado ao decorrer do texto.

Tendo o exposto acima, este trabalho se preocupa em tratar de uma obra desse território: o romance Meia Vida, de V.S. Naipaul. Publicado em 2001, sob o título Half a Life, a obra se inclui na discussão pós-colonial ao apresentar a Índia recém-independente aos olhos do protagonista, Willie Somerset Chandran, que descreve uma sociedade ainda baseada em castas sociais, nas quais não se enquadra por ser filho de uma mãe de uma casta considerada inferior e de um pai brâmane, uma casta superior. Marginalizado em seu próprio país, e percebendo que vivia uma "meia vida" na Índia, Chandran decide que é chegada a hora de 
encontrar a sua verdadeira identidade e, portanto, peregrina pela Inglaterra e depois pela África em busca de autoconhecimento.

O romance, publicado no mesmo ano em que V.S. Naipaul foi laureado com o Prêmio Nobel de Literatura, trata de questões peculiares ao pós-colonialismo, como a condição de deslocamento do colonizado, a crise de identidade, e a preservação de uma sociedade ainda hostil ao indivíduo. Além disso, as questões culturais indianas são apresentadas por um escritor cuja formação cultural e intelectual ocorreu em múltiplos contextos (Trinidad e Tobago, Índia e Inglaterra).

É importante salientar que os Estudos Pós-Coloniais (teoria e romance póscoloniais) se articulam com diversas áreas do saber, entre elas os Estudos da Tradução, como destaca Boaventura de Sousa Santos:

Entendo por pós-colonialismo um conjunto de correntes teóricas e analíticas, com forte implantação nos estudos culturais, mas hoje presentes em todas as ciências sociais, que têm em comum darem primazia teórica e política às relações desiguais entre o Norte e o Sul na explicação ou compreensão do mundo contemporâneo. (SANTOS, 2008, p. 18)

Além da questão linguística, que capacita um leitor brasileiro ou não familiarizado com a língua inglesa, a ler escritos em inglês, a tradução literária de romances pós-coloniais possibilita aumentar a sua abrangência, ao torná-los acessíveis em culturas distintas das que os originou.

Ao tratarmos de um texto com prestígio internacional, que é o caso de Meia Vida, mas que trata de culturas minoritárias, nos vem a seguinte pergunta: Como traduzi-lo? Quais aspectos linguísticos e culturais o tradutor deve levar em conta ao traduzir textos literários pós-coloniais? O que leva as editoras mundo afora a escolher esses tipos de texto para serem traduzidos? É por meio do estabelecimento de articulações entre os Estudos Pós-Coloniais e os Estudos da Tradução e da análise do romance Meia Vida no original e na sua tradução que essas questões serão discutidas ao longo do texto.

Para este artigo, primeiramente realiza-se uma exposição teórica sobre a questão da tradução de textos literários pós-coloniais. Em seguida, apresenta-se um rápido panorama conceitual do pós-colonialismo e suas teorias. E, finalmente, empreende-se uma análise do romance pós-colonial Meia Vida, tanto do seu texto originário em inglês, quanto da sua tradução para o português, levando em consideração aspectos linguísticos e extralinguísticos. Finalizando o artigo, inclui-se uma entrevista com a tradutora, Isa Mara Lando.

\section{Fundamentação teórica}

A problemática de tradução de textos literários pós-coloniais é discutida por Maria Tymoczko em "Post-colonial Writing and Literary Translation", primeiro capítulo do livro Post-colonial Translation: Theory and Practice, editado por Susan Bassnett e Harish Trivedi. Nesse capítulo, a autora pontua alguns aspectos relevantes que se deve levar em consideração ao traduzir textos literários pós- 
coloniais. Para ela, o primeiro desafio do tradutor é que ele enfrenta um texto planejado para um público específico da cultura fonte que é produzido e, consequentemente, a questão da fidelidade da tradução em relação ao texto fonte é posta em debate. De acordo com Tymoczko (2002, p. 23) "o tradutor deve decidir como lidar com as características da cultura fonte (...) que são estranhas ao público receptor, adaptando e modificando o texto fonte no processo"3. Ainda de acordo com Tymoczko, a tradução de textos literários pós-coloniais será obviamente mais longa por conta dessas adaptações e modificações do texto fonte. Portanto, para ela "a seleção (do tradutor) é essencial para a construção de qualquer texto literário, especialmente quando o público alvo inclui leitores que não estão familiarizados com os aspectos culturais desse texto" ${ }^{4}$ (TYMOCZKO, 2002, p. 23).

Dessa forma, o primeiro aspecto a ser analisado em Meia Vida, em sua tradução para o português brasileiro, será observar as decisões interpretativas tomadas durante o processo tradutório da obra. Para Tymoczko (2003, p. 24), "o processo de seleção e interpretação é ideológico e inevitavelmente gera controvérsia". ${ }^{5}$ Nesse ponto em questão, a seguinte hipótese é levantada: a escolha da editora em traduzir Meia Vida, dentre tantos outros romances pós-coloniais, pode ser tanto ideológica, contemplando o ponto de vista de Tymoczko, quanto mercadológica, pelo fato de publicar um autor premiado cuja obra terá impacto no mercado editorial. É possível também indagar-se sobre o motivo da escolha da tradutora e da obra a ser traduzida, que também podem refletir em algum nível, a(s) ideologia(s) da editora.

Essa hipótese tem suporte no que Tymoczko (2002) e Lefevere (2007) chamam de patronagem ou mecenato. De acordo com Lefevere (2007, p. 34), o mecenato deve ser entendido "como algo próximo dos poderes (pessoas, instituições) que podem fomentar ou impedir a leitura, escrita e reescritura de literatura". Os mecenas, representantes do mecenato, que "antes eram representados por ricos aristocratas, agora assumem a forma de revistas e jornais, editoras e universidades" 6 (TYMOCZKO, 2002, p. 30). Operando por meio dessas instituições, "os mecenas determinam os parâmetros do que é traduzido, bem como determinam os parâmetros do que é publicado"' (TYMOCZKO, 2002, p. 30). Aspectos ideológicos das traduções pós-coloniais, especialmente da tradução de Meia Vida, são tratados mais adiante, na seção de análise deste estudo.

Outro aspecto extralinguístico ressaltado por Tymoczko (2002, p. 28) na tradução de textos literários pós-coloniais é que o tradutor(a) deve saber qual será o público alvo de sua tradução, se ele tem bases culturais, históricas e sociais para o entendimento de textos literários pertencentes a outras culturas. Sabendo disso, o tradutor se sentirá mais à vontade para ser mais ou menos explícito em relação às mudanças linguísticas e culturais a serem efetuadas na tradução. De qualquer forma, o tradutor enfrentará um dilema: “(...) produzir textos com uma enorme quantidade de material que se tornará obscuro ou ininteligível para os

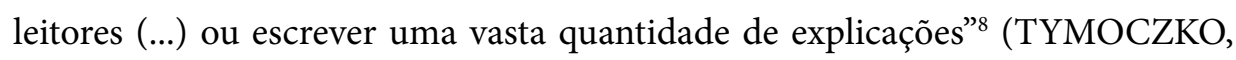
2002, p. 29). Para a autora, o tradutor deve levar esses aspectos em consideração visando à literariedade do texto. 
Finalizando esse tópico, Tymoczko (2002, p. 29) afirma que "nos Estudos da Tradução é geralmente feita uma distinção entre 'trazer o texto para o público' e 'trazer o público para o texto"'. Isso quer dizer que algumas traduções irão exigir um conhecimento e uma conformidade do leitor em relação a crenças, costumes e linguagem do texto fonte, enquanto outras traduções procurarão se adaptar à cultura e à linguagem do público receptor. Entretanto, a opção do tradutor em trazer o texto para o público ou trazer o público para o texto, de acordo com Tymoczko, tem a ver com o prestígio do texto e da cultura fonte a serem traduzidos. A autora afirma que "em traduções, quanto maior o prestígio da cultura fonte e do texto fonte, mais fácil é pedir que o público venha até o texto"10 (TYMOCZKO, 2002, p. 29). Inclusive, o prestígio do autor é levado em conta: "quanto maior for a reputação do autor, maiores serão as exigências que podem ser postas frente a um público internacional"11 (TYMOCZKO, 2002, p. 29). No decorrer do presente artigo, as questões de levar o texto ao público, ou levar o público ao texto na tradução de Meia Vida, são mais detalhadamente discutidas.

Após tratarmos de alguns aspectos da tradução de textos literários póscoloniais, agora aborda-se o termo pós-colonialismo, crucial para este trabalho. Do ponto de vista teórico, ele é definido como um conjunto de correntes teóricas e analíticas que questionam as relações constituídas pelo colonialismo nos países do Terceiro Mundo.

Para Bonicci (1998, p. 10):

As teorias pós-coloniais podem ser entendidas como uma abordagem alternativa para compreender o imperialismo e suas influências, como um fenômeno mundial e, em menor grau, como um fenômeno localizado. Esta abordagem envolve: um constante questionamento sobre as relações entre a cultura e o imperialismo para a compreensão da política e da cultura na era da descolonização. (BONNICI, 1998, p. 10)

Após a Segunda Guerra Mundial (1939-1945) houve uma onda de descolonização na África, Ásia e Caribe, causada principalmente pelo enfraquecimento político e econômico dos países que detinham colônias nesses continentes. Nesse período pós-guerra, várias colônias conquistaram a independência política de países europeus, como a Índia, em 1947, Trinidad e Tobago, em 1962, Quênia, em 1963, e a Nigéria, em 1960, apenas para citar exemplos de ex-colônias britânicas. Essa independência política, entretanto, parece não constituir uma emancipação plena em relação aos antigos colonizadores, pois de acordo com Stuat Hall as histórias imperiais "continuam a ser vivamente retrabalhadas, são necessariamente, portanto, momentos de luta cultural, de revisão e de reapropriação" (HALL, 2003, p. 34). Essa conjuntura sinaliza para uma quebra do "discurso natural(izado), unificador, da 'nação', dos 'povos"' (BHABHA, 2013, p. 277). Portanto, após esse período de dominação política europeia, esses povos preocupam-se em reconhecer as suas histórias e reinterpretá-las sob um novo viés.

De acordo com Bhabha (2013, p. 278): 
A perspectiva pós-colonial (...) tenta revisar aquelas pedagogias nacionalistas ou "nativistas" que estabelecem a relação do Terceiro Mundo com o Primeiro Mundo em uma estrutura binária de oposição. A perspectiva pós-colonial resiste à busca de formas holísticas de explicação social. Ela força um reconhecimento das fronteiras culturais e políticas mais complexas que existem no vértice dessas esferas políticas frequentemente opostas. (BHABHA, 2013, p. 278)

Assim sendo, após a Segunda Guerra Mundial, há um deslocamento cultural, representado principalmente pela maciça migração do Terceiro Mundo para o Ocidente (BHABHA, 2013, p. 277). Decorrente desses deslocamentos, as identidades culturais e políticas desses sujeitos pertencentes às ex-colônias europeias passam a ser repensadas, não sendo mais vinculadas ao pensamento colonizador, mas ainda, de certa forma, ligadas a ele.

Desse modo, as configurações da identidade se tornam importantes no debate pós-colonial, pois tendem a gerar nos sujeitos inseridos nesse contexto uma condição de deslocados culturais, visto que eles não se sentem pertencentes nem à cultura do país que nasceram, nem à cultura de um país europeu. Dessa indefinição, aflora um ser cultural híbrido.

Em relação às diferenças culturais, Bhabha (2013, p. 284) afirma:

cada vez mais, o tema da diferença cultural emerge em momentos de crise social, e as questões de identidade que ele traz à tona são agonísticas; a identidade é reivindicada a partir de uma posição de marginalidade ou em uma tentativa de ganhar o centro: em ambos os sentidos, ex-cêntrica. (BHABHA, 2013, p. 284)

Sendo assim, a temática da diferença cultural adentra o campo da literatura e das outras artes, ficcionalizando o debate a partir da apropriação das formas e do idioma da narrativa europeia, de acordo com o argumento de Coutinho (2003) ao tratar das literaturas pós-coloniais. Para o autor:

As literaturas pós-coloniais desafiam a visão do mundo ocidental, apropriam-se criticamente das formas e do idioma da narrativa europeia e põem em xeque seus pressupostos filosóficos. A Teoria Pós-Colonial, em suma, revisita, relembra e sobretudo questiona o passado colonial, afirmando que não há neutralidade e universalidade nos estudos literários. (COUTINHO, 2003, p. 94)

Sendo assim, a colonização e seus desdobramentos passam a ser analisados a partir de diferentes prismas e áreas do conhecimento, e cabe às vozes da literatura pós-colonial rediscutir a representação ocidental desses povos e culturas afetados pelo colonialismo usando um viés ficcional, e não teórico. Esses escritos tendem a apostar em narrativas que exploram a diversidade cultural desses lugares/sujeito descritos como um elemento enriquecedor e único.

Portanto, na literatura pós-colonial, o foco está na periferia, e não mais no centro. De forma resumida, entendemos o termo periferia como o que designa os países que anteriormente foram colônias europeias, e centro como os antigos colonizadores. Assim, sujeitos que antes não tinham voz, e que, principalmente, 
não eram ouvidos, tomam a palavra na literatura pós-colonial. De acordo com Mascena e Lúcio (2011, p. 2):

As vozes silenciadas pelo sistema imperialista e colonizador passam a ganhar espaço entre os críticos literários e culturais. O olhar, antes focado apenas para o centro, começa a desviar-se para inúmeras direções, principalmente para a periferia. (MASCENA, LÚCIO, 2011, p. 2)

Por fim, com esse sujeito tendo voz, via literatura e teoria, e as questões coloniais postas em debate, se faz interessante saber como essas vozes coloniais vêm sendo ouvidas e interpretadas mundo afora pela tradução literária. Procuramos, agora, investigar se os clamores dos sujeitos coloniais, a sua cultura e linguagem são mantidos ou suprimidos na tradução elencada.

\section{Análise}

O romance Half a Life, de V.S. Naipaul, publicado originalmente em 2001 pela editora Alfred A. Knopf, de Nova Iorque, foi publicado no Brasil sob o título Meia Vida, em 2002 pela editora Companhia das Letras, e traduzido para o português pela tradutora Isa Mara Lando. Começamos essa análise, primeiramente, falando dos motivos ideológicos que podem ter motivado a tradução dessa obra póscolonial para o português. ${ }^{12}$

Entretanto, Half a Life não foi a primeira obra do autor a ser traduzida para o Português. O primeiro romance de Naipaul que chegou ao Brasil foi The Mimic Men (Os Mímicos), em 1987, em tradução de Paulo Henriques Britto, e publicado pela Companhia das Letras. A editora, inclusive, é a única a editar as obras de V.S. Naipaul no Brasil até o momento, tendo lançado desde 1987 um total de dezesseis obras (ficção e não-ficção) em seu catálogo. ${ }^{13} \mathrm{~A}$ tradução de Naipaul no Brasil ficou a cargo de renomados tradutores brasileiros, como Paulo Henriques Britto, Isa Mara Lando, Marcos Bagno, Rubens Figueiredo, entre outros.

Embora o sucesso editorial das obras de V.S. Naipaul anteriores à publicação de Half a Life no Brasil justifique parcialmente o motivo de sua tradução, é possível fazer uma análise mais detalhada, elencando outros prováveis motivos que podem ter levado à tradução dessa obra, bem como às anteriores. De acordo com Tymoczko (2002, p. 30), "os Estudos da Tradução estão cada vez mais atentos às circunstâncias com as quais livros são escolhidos para serem traduzidos e publicados". ${ }^{14}$

Um dos motivos é agradar o centro e a periferia, sem abrir mão da crítica pós-colonial. Essa maleabilidade de satisfazer ambos pode ter origem em sua própria biografia. É importante mencionar que V.S. Naipaul, nos seus primeiros anos, escreve de e sobre um país periférico, as ilhas caribenhas de Trinidad e Tobago, ex-colônia britânica, mas só obtém prestígio internacional ao fixar residência em Londres, nos anos de 1950, e ter seu primeiro livro publicado em 1957 (O Massagista Místico). Quando os seus livros começam a ganhar destaque no final de década, ele já vivia em Londres há pelo menos dez anos. Portanto, o 
conceito de mecenato poderia, a partir de então, ser aplicado aos escritos dele, visto que suas obras obtiveram notoriedade mercadológica e crítica após seu reconhecimento como escritor. Para Tymoczko (2002, p. 31) "as exigências do mecenato internacional irão comprometer a forma, o conteúdo e a perspectiva das próprias obras pós-coloniais". ${ }^{15}$

Embora, na maioria de suas obras, Naipaul escreva sobre o mundo colonial em que viveu e ao qual pertence, e a temática do deslocamento colonial pósguerra seja aplicada a ele próprio, quando escreve Meia Vida parece adaptar o discurso literário a uma audiência internacional, e não local. Portanto, a obra pode ser classificada como um romance pós-colonial que trata dos costumes, cultura e sociedade indianas, mas que não foi diretamente escrito para os povos de cultura indiana, mas para uma audiência global, porquanto exige pouco conhecimento cultural do leitor em relação aos costumes de lá.

Um tom explicativo/didático é percebido em dois momentos na própria obra, exemplificando a adequação do texto ao leitor internacional. Esses trechos são transcritos aqui no original em inglês e em tradução para o português brasileiro:

Privately, in the recesses of my heart, I took a vow of sexual abstinence, a vow of brahmacharya (NAIPAUL, 2001, p. 32-33).

Em particular, no recesso do meu coração, fiz um voto de abstinência sexual, ou brahmacharya (NAIPAUL, 2002, p. 36).

\section{(...)}

The journalist replied first. Dean Chandran, Of course I remember your father. My favourite babu... "Babu," an anglicised Indian, was a mistake; the word should have been "sadhu," an ascetic (NAIPAUL, 2001, p. 53).

O jornalista respondeu primeiro. Prezado Chandran, claro que me lembro de seu pai. Meu babu predileto... "Babu", palavra indiana anglicizada, era um erro; a palavra correta deveria ser sadhu, asceta (NAIPAUL, 2002, p. 54).

Desses trechos podemos inferir algumas considerações. Primeiramente, a de que mesmo Naipaul sendo um autor de enorme prestígio não exige uma adaptação dos seus leitores a uma cultura distinta, e ele próprio torna-se até didático ao apresentar aos leitores um universo cultural distinto do seu público, que deduzimos ser uma audiência global, e não local. Isso, de certa forma, nos permite dizer que o mecenato influencie a sua escrita, pois podemos imaginar que um texto pleno de referências culturais inexplicadas não alcance um público tão abrangente. Isso, consequentemente, afetaria o seu prestígio internacional e o número de editoras interessadas em traduzir o romance.

$\mathrm{Na}$ tradução, o didatismo auxilia ainda mais o leitor, pois a cultura indiana é pouquíssimo conhecida e difundida no Brasil. Dados apontam que a comunidade indiana no Brasil se restringe a cerca de cinco mil pessoas, que vivem em grandes metrópoles como São Paulo e Rio de Janeiro. ${ }^{16}$ Números esses que são categoricamente opostos aos de pessoas de origem indiana na Inglaterra e País de 
Gales, que de acordo com o censo de $2011^{17}$ somam 1 milhão e 400 mil pessoas, o que corresponde a $2,5 \%$ da população desses dois países.

Mesmo habitando a Inglaterra há muito tempo, e sendo conhecedor da extensão da comunidade indiana na Grã-Bretanha, Naipaul não usa um excessivo número de vocábulos da língua hindi ou derivados dela, o que nos leva a crer que a obra, de fato, não se destina nem ao grupo étnico de indianos na Inglaterra, nem à população indiana em específico, mas sim a um leitor global.

No total, em Meia Vida, encontramos algumas palavras ligadas ao idioma hindi, o qual é falado por cerca de $70 \%$ dos indianos. São elas brahmacharya, ashram, dhoti, babu, shadu, maharaja e Kama Sutra. Em relação a elas, brahmacharya, babu e shadu são explicadas dentro do próprio texto. Os vocábulos brahmacharya, babu, ashram, dhoti e maharaja já estão dicionarizados, conforme consulta ao Dicionário Random House Webster's Unabridged (1997). A inclusão dessas palavras na língua inglesa também é constatada ao checarmos o Oxford Advanced Learner's Dictionary (2005) e a versão online do Oxford English Dictionary. ${ }^{18}$ Os dois dicionários listam os mesmos termos, com exceção de brahmacharya. Já Kama Sutra, que tem sua definição explicada apenas pela versão online do Oxford English Dictionary, ${ }^{19}$ é um substantivo próprio que ganhou fama mundial ao se tratar de um livro sobre a arte do sexo, bastante popularizado no ocidente.

$\mathrm{Na}$ tradução para o português as palavras ashram e dhoti são grafadas em itálico, diferente da versão original. Um dos possíveis motivos é de elas não estarem dicionarizadas em português, à exceção de $b a b u$, única palavra de origem hindi dicionarizada, conforme consulta ao Dicionário Novo Aurélio Século XXI (1999). Ao buscar as referidas palavras no Dicionário Michaelis online $e^{20}$ não foram encontradas definições para nenhum desses vocábulos. Já maharaja é traduzida para marajá, o seu equivalente em português. Essa palavra não é colocada em itálico, pois se encontra dicionarizada e seu significado original já foi, inclusive, ampliado, ganhando novos significados na nossa língua. Por sua vez, o título do livro Kama Sutra é mantido em itálico, pois também continua não-dicionarizado. Além da observação sobre a dicionarização de um vocábulo, o tradutor, muitas vezes, segue o manual de redação e estilo de cada editora, que define a padronização de destaques das palavras do texto.

Não sendo uma grande barreira ao entendimento do texto, os elementos da cultura indiana na tradução, escassos, bem explicados, ou popularizados em nível mundial, não interferem no aspecto pós-colonial do romance, pois o sentimento de deslocamento ainda é latente na figura do protagonista.

O fato de não haver tantas referências à cultura indiana no romance pode ter duas explicações. A primeira, já tratada, seria a influência do mecenato, que confere à obra e ao escritor o status de prestígio que ele tem, garantindo a Naipaul viver exclusivamente da literatura. Por exemplo, o mundo indiano recriado por Naipaul não reflete de forma aberta a relação historicamente conturbada entre Índia e Inglaterra. Podemos então dizer que, nesse aspecto, Naipaul aceita o mecenato, pois segue um padrão narrativo consagrado, pois que Meia Vida é um 
romance de estrutura linear cuja narrativa aborda a preservação da estabilidade do sistema social de língua inglesa.

Para Lefevere (2007, p. 36) o mecenato possui três componentes: o ideológico, o econômico e componente de status, os quais são fornecidos pelos mecenas. Considerando isso, conjeturamos um alinhamento de Naipaul às normas do mecenato inglês, adaptando Meia Vida ao sistema literário de língua inglesa, não sendo dissidente nesse sentido. A outra explicação é que as parcas referências à cultura indiana no romance podem ter sido construídas pelo autor justamente como um desdobramento do colonialismo inglês em terras indianas, exercendo um impacto no protagonista, que não se vê como um indiano.

O alinhamento ao mecenato pelo autor e a disposição do romance dentro de uma estrutura narrativa linear e bem vista dentro do sistema literário de língua inglesa obtiveram o respaldo dos críticos, resenhistas, professores e tradutores. Estes, que constituem a instituição literária, de acordo com Lefevere (2007, p. 33-34), "são profissionais que podem rejeitar alguma obra literária que se oponha de forma muito evidente ao conceito dominante do que a literatura deveria ser". Assim, Meia Vida é um romance que, potencialmente, agrada o centro, por seguir padrões literários consagrados, e a periferia, por tratar de culturas minoritárias, favorecendo assim a sua tradução e um maior alcance mundial.

Apesar de não conter muitas referências à cultura indiana, o romance possui diversas menções à cultura de língua inglesa. Nomes de romances, bairros de Londres, filmes e diretores de filmes, são várias referências que apenas um leitor bastante familiarizado com a cultura de língua inglesa saberia identificar. Provavelmente um leitor britânico/americano interpretaria melhor essas referências do que um leitor brasileiro. Como a segunda parte do romance se passa em Londres, essas referências são abundantes:

His father saw him one day asleep face down, a close copy of a school edition of The Vicar of Wakefield beside him, his feet crossed, the red soles much lighter than the rest of him. (NAIPAUL, 2001, p. 47)

Seu pai o viu certo dia dormindo de bruços, com um livro fechado ao lado, uma edição escolar de $O$ vigário de Wakefield, os pés cruzados, as solas avermelhadas, de uma cor muito mais clara do que o resto do corpo. (NAIPAUL, 2002, p. 48)

She works at the perfume counter in Debenhams. (NAIPAUL, 2001, p. 61)

Trabalha no balcão de perfumes da Debenhams. (NAIPAUL, 2002, p. 61)

The taxi took them away from the enchanted area of Marble Arch and Bayswater. (NAIPAUL, 2001 p. 65)

O táxi os levou embora, saindo da área encantada de Marble Arch e Bayswater. (NAIPAUL, 2001 p. 64)

Reforço do alinhamento de Naipaul à cultura de língua inglesa é o fato de ele não detalhar tanto as passagens do protagonista do romance, Willie Somerset 
Chandran, pela Índia e por Moçambique, não nomeando as cidades, ruas, ou citando obras literárias desses países, assim como ele faz com inúmeras referências à Inglaterra e aos Estados Unidos na obra. Uma curiosa passagem no livro traz um diálogo entre Willie e Roger, em cujo trecho Willie revela a dificuldade em inserir a Îndia na temática de sua obra: "O conto é sempre um gênero difícil, e, para falar a verdade, a Índia não é um tema. As únicas pessoas que vão ler sobre a Índia são as que já viveram ou trabalharam lá” (NAIPAUL, 2002, p. 93). Willie Chandran e V.S. Naipaul possuem muitas semelhanças, como o fato de ambos saírem de ex-colônias britânicas, passarem a morar na Inglaterra, e serem escritores, mas essa análise do romance como uma espécie de autobiografia de Naipaul será matéria para uma outra ocasião.

Para o leitor brasileiro do romance traduzido, as referências da cultura inglesa parecem ser mais complicadas do que aquelas da cultura indiana, pois as primeiras são mais numerosas e não explicadas. A tradutora Isa Mara Lando, que já traduziu 30 livros somente pela editora Companhia das Letras, opta por não colocar notas de rodapé nessas referências à cultura inglesa e de um modo geral traduzir os títulos de livros (com exceção de um) e filmes apresentados durante a narrativa, mas não traduzir logradouros e outros nomes próprios, como podemos ver nos trechos a seguir:

Ouvi dizer que você não sabia nada de nada sobre os românticos, nem sobre The Mayor of Casterbridge. (NAIPAUL, 2002, p. 24)

Alguns dias depois foi a uma livraria. Por dois shillings e seis pence comprou uma edição Penguin das primeiras histórias de Hemingway. Leu as quatro páginas de "Os assassinos" ainda em pé na livraria. (NAIPAUL, 2002, p. 78)

Pensou, em especial, nos filmes de gângster de James Cagney e em Seu último refúgio, com Humphrey Bogart. (NAIPAUL, 2002, p. 79)

É isso que os missionários fizeram com ele, com Mom e Pop, e Dick Tracy, e a revista em quadrinhos da Justice Society of America (...). (NAIPAUL, 2002, p. 47)

Percebemos que, no romance originário, a cultura indiana chega até o leitor internacional com vários termos em hindi bastante difundidos no ocidente, principalmente no Reino Unido, como resultado de anos de colonização. Além disso, o livro está repleto de referências americanas e britânicas, que são conhecidas mundialmente e, portanto, não exigem uma pesquisa cultural por parte desse leitor global. Já o leitor brasileiro, ao se deparar com a tradução, é aproximado da cultura indiana via Naipaul, que explica as referências dessa cultura no texto originário. Porém, o leitor da tradução brasileira é aproximado dos elementos culturais ingleses pela tradutora, que não os domestica no seu texto.

Apesar de a obra se aproximar mais da cultura de língua inglesa do que da cultura indiana, por meio das escolhas lexicais como já ressaltado anteriormente, isso não torna o livro menos pertencente à literatura pós- 
colonial. Isso posto, a partir de agora, trataremos dos elementos póscoloniais em Meia Vida, no texto originário e na sua tradução, observando a transposição e manutenção desses aspectos.

Após minuciosa leitura do romance, com a finalidade de descrever suas características pós-coloniais, observou-se na narrativa um predomínio dos seguintes pontos: a condição de deslocamento, a crise de identidade, a falta de senso de pertencimento, o dilema do imigrante e o hibridismo cultural. No romance, Naipaul apresenta personagens que são produtos de uma mistura racial e cultural e mostra como eles lutam para construir a própria identidade em uma sociedade multicultural. A seguir, apresentamos alguns trechos que podem exemplificar essas características, tanto no romance em inglês, quanto na tradução:

He was unanchored, with no idea of what lay ahead. (NAIPAUL, 2001, p. 56)

Não tinha âncora, não tinha idéia (sic) do que havia à sua frente. (NAIPAUL, 2002, p. 56)

Willie began to understand that he was free to present himself as he wished. He could, as it were, write his own revolution. The possibilities were dizzying. He could, within reason, remake himself and his past and his ancestry. (NAIPAUL, 2001, p. 57)

(...), e ele compreendeu que estava livre para apresentar-se da maneira que quisesse. Podia, por assim dizer, escrever sua própria revolução. As possibilidades eram estonteantes. Ele podia, dentro dos limites da razão, refazer a si mesmo, seu passado e seus ancestrais. (NAIPAUL, 2001, p. 57)

The learning he was being given was like the food he was eating, without savour. (NAIPUL, 2001, p. 56)

O ensino que estava recebendo era como o alimento que comia, sem sabor. (NAIPAUL, 2002, p. 56)

Nesses trechos selecionados, o protagonista, Willie Somerset Chandran, recém-chegado a Londres, cidade que carrega todo o valor simbólico de ser a capital do antigo Império Britânico, sente-se perdido, e está em busca da descoberta da própria identidade, para que possa reescrever a sua história e apagar o seu passado indiano, considerado por ele inferior. Contudo, pouco tempo depois, vê-se frustrado com o ensino formal que recebia na escola, descrito por ele como "sem sabor", ou em outras palavras, sem sentido.

Ao tentar uma carreira de escritor na Inglaterra, frustra-se ainda mais, e não consegue encontrar sentido em sua "meia vida" - nem Índia, nem Londres. Por meio da escrita e do ensino formal em uma universidade, Chandran percebe que não se adapta ao mundo de aparências de Londres e decide partir com Ana em direção a Moçambique, que naquele tempo, estava em processo de independência política de Portugal. ${ }^{21}$ Ana fora uma das poucas pessoas que o leram e compreenderam, e com quem se casou. 
Ao chegar ao país africano, Chandran incomoda-se ainda mais devido à língua e às culturas diversas, o que gera, mais uma vez, o sentimento de nãopertencimento ao local que acabara de chegar, como podemos perceber nos seguintes excertos:

I don't know where I am. I don't think I can pick my way back. I don't ever want this view to become familiar. I must not unpack. I must never behave as though I am staying. (NAIPUL, 2001, p. 126)

Não sei onde estou. Acho que não consigo encontrar o caminho de volta. Não quero que esta paisagem se torne familiar, nunca. Não devo desarrumar a mala. Não devo jamais me comportar como se eu fosse ficar aqui. (NAIPAUL, 2002, p. 119)

I always felt a stranger in the house. I never got used to the grandeur; the furniture seemed strange and awkward right to the end. (NAIPAUL, 2001, p. 141)

Eu sempre me senti como um estranho na casa. Nunca me acostumei com a grandiosidade; até o final aquela mobília me parecia estranha e desgraciosa. (NAIPAUL, 2002, p 133)

Como podemos ver nesses trechos, as questões pós-coloniais parecem ser pontuadas tanto na tradução, quanto no original. Na tradução, ressaltamos em dois momentos o uso dos advérbios "não" e "nunca". No primeiro momento, os advérbios "não" e "nunca" sugerem ênfase à negação da vida que estava vivendo, e aparentam refletir seu deslocamento. No segundo momento, o uso do advérbio "não" pode representar o quão perdido o protagonista se sentia em Londres:

Não tinha âncora, não tinha idéia (sic) do que havia à sua frente. (NAIPAUL, 2002, p. 56)

Não sei onde estou. Acho que não consigo encontrar o caminho de volta. Não quero que esta paisagem se torne familiar, nunca. Não devo desarrumar a mala. Não devo jamais me comportar como se eu fosse ficar aqui. (NAIPAUL, 2002, p. 119)

Por fim, ressaltamos que, na tradução de Isa Mara Lando, os aspectos póscoloniais da obra, majoritariamente presentes nas escolhas lexicais, são mantidos e realçados. A tradução possibilita que o leitor aprofunde as suas percepções das culturas indiana, inglesa e moçambicana, além de apresentar temas cruciais ao pós-colonialismo, como a condição de deslocado do colonizado e de sua identidade híbrida.

Além das análises bibliográficas realizadas neste estudo, procedeu-se uma entrevista via e-mail com a tradutora, a fim de melhor compreender as opções tradutórias por ela empregadas. Foram indagadas oito perguntas, a partir das quais obtiveram-se subsídios para a discussão a seguir. 
Ao ser questionada sobre a não inclusão de notas do tradutor, e ressaltando que Meia Vida, tanto no original, quanto na tradução não contém notas de rodapé, Lando responde que: "Notas de tradução devem ser evitadas ao máximo em obras de ficção, pois interrompem a leitura e cortam o barato do leitor. Essa é a orientação da maioria das editoras. É melhor reduzi-las ao mínimo indispensável" (LANDO, 2017).

Ao ser inquirida sobre as suas escolhas tradutórias, se prefere ocultar as diferenças culturais, adaptando tudo à cultura de chegada, ou se procura manter a estranheza do texto original e da cultura de partida, Lando responde:

Depende do livro, mas de modo geral acho que quem lê um livro sobre a África está interessado na África e na cultura africana. Vez por outra posso adaptar algo para o leitor entender. No caso de livros infantis, que eu gosto muito de fazer, eu adapto mais, por exemplo: "Acho que ela comprou essa tiara na loja do 1,99!” (Devia ser Dollar Dreams ou algo assim.) É interessante notar que a palavra tra-duzir vem de trans-ducere, levar através. Isso pode ser interpretado de duas maneiras: você pode levar o leitor para a África, ou então trazer a África para o leitor. Como eu sempre li muito Mark Twain, Jack London em criança e adolescente, sempre gostei de viajar para lá. Quero ir para o Alasca, para o Mississippi, quero conhecer a cultura de lá. (LANDO, 2017)

Além dessas respostas, Lando ainda afirma, quando perguntada se já conhecia o autor e a obra, e se havia interesse da parte dela em traduzir outros autores que escrevem obras pós-colonialistas, ${ }^{22}$ ela respondeu que não conhecia o autor nem a obra no momento que foi convidada pela editora a traduzir o romance, e que não cabe ao tradutor escolher as obras que traduz, reduzindo o fato dela ter traduzido V.S. Naipaul, Salman Rushdie e Chinua Achebe grandes nomes da literatura pós-colonial a uma "coincidência":

A editora é que escolhe quais livros vai publicar e quem vai chamar para traduzir (...). Pode acontecer de um tradutor ou outra pessoa sugerir um título à editora, chama-se indicação editorial. Mas se ela aprovar e decidir publicar, também não quer dizer que vai chamar para traduzir esse mesmo que indicou. (LANDO, 2017)

Perguntada sobre as dificuldades da tradução e os desafios no processo tradutório, Lando respondeu que: "Não senti necessidade. Naturalmente, vou pesquisando o vocabulário enquanto vou fazendo" (LANDO, 2017). Em relação às dificuldades no processo tradutório, ela afirma:

Não me lembro das dificuldades de tradução, que naturalmente, sempre aparecem. Acho tradução um trabalho difícil, mentalmente e até fisicamente. Sempre tem dificuldades, mas no caso, não me lembro" (LANDO, 2017). 
Ao ser questionada sobre as explicações dos tradutores nas traduções literárias, Lando afirma:

Explicações sobre escolhas tradutórias não cabem no livro. Só raramente há uma troca de ideias com a editora a respeito de alguma coisa que eles estranharam. Mas isso não chega até o leitor. Só alguém especializado como você se interessa por isso. O leitor comum quer ler um livro bem traduzido, quer viajar na história com um bom texto em português, só isso, e merece isso.

Isa Mara Lando, hoje com setenta e um anos, e uma extensa bibliografia como tradutora e autora (de livros infantis e de ensino de língua inglesa), revela, após quinze anos da sua versão em português de Half a Life, que não gostou muito dela, e que não traduz ficção há anos, exceto livros infantis:

Achei esse livro chato e fraquíssimo [...]. A meu ver se fosse assinado por João da Silva e não por Naipaul, Prêmio Nobel, ninguém iria publicar [...]. Meu interesse é não-ficção. Ficção não traduzo mais há vários anos, exceto infantil, pois é muito difícil conseguir um bom resultado, principalmente nos diálogos. A gramática da língua portuguesa é muito rígida e nos obriga a escrever de um jeito muito diferente do nosso jeito normal de falar. Isso dá uma dor de cabeça louca pra traduzir. Não se pode nem escrever: "Me dá essa carta." Nem "Eu te amo!" Se alguém chamar o outro de você, tem que ser "Eu o amo", ou Eu a amo. Já viu uma palhaçada maior? Então não faço. (LANDO, 2017)

A prática de cada profissional é peculiar, e Lando, experiente, parece agir com muito profissionalismo e respeito em relação à obra, mesmo ao afirmar não ter gostado dela no original. A sua tradução revelou a manutenção e reafirmação de itens culturais dos contextos envolvidos na obra, bem como possibilitou ao leitor brasileiro entrar em contato com essas realidades.

\section{Considerações finais}

Este artigo discutiu de que maneira os Estudos da Tradução e os Estudos Póscoloniais podem se interligar, destacando a maneira com a qual, via literatura, tradução e pós-colonialismo podem interagir. Também foi debatida a forma com que os tradutores podem lidar com textos literários pós-coloniais, ressaltando as suas peculiaridades culturais sobre as quais os tradutores devem estar alertas.

Além disso, procurou-se discutir aspectos ideológicos que motivam a tradução de textos coloniais, exemplificando o caso de Meia Vida, de V.S. Naipaul, autor laureado com um Prêmio Nobel e que escreve sobre a população periférica de origem indiana. Por fim, ao analisarmos o romance Meia Vida e seu original, buscou-se perceber, na tradução, as formas de transposição dos aspectos culturais e lexicais. Ainda almejou-se saber a ligação entre esses aspectos e a tradução pós-colonial.

Por fim, por meio da entrevista realizada com a tradutora da obra, Isa Mara Lando, pode-se adentrar nos caminhos sinuosos do mundo tradução. Através 
dessa entrevista foi possível ter uma noção de como as editoras operam e de como a prática tradutória de Lando se concretiza.

É importante dizer que ainda há questões a serem respondidas que este artigo não obteve mérito, mas já, de alguma forma, conjeturou. Há outros aspectos, além dos elencados neste texto, que são relevantes ao se traduzir textos literários pós-coloniais? Quais são as diferenças entre traduzir um texto ficcional "padrão" e um texto literário pós-colonial? Qual é o papel efetivo dos tradutores nessas traduções? Como ele pode influenciar na tradução de um texto literário pós-colonial? Qual é a importância que as editoras dão a essas obras e por quais outros motivos, além dos mencionados no texto, eles vêm sendo traduzidos?

As questões são muitas, e geram material para uma nova pesquisa, mas o que se percebeu é que obras ficcionais pós-coloniais se apresentam como um desafio singelo ao tradutor, que se vê diante de textos com fartos elementos culturais, próprios de sociedades ainda pouco conhecidas no Brasil. Nesse sentido, os tradutores podem escolher, a partir de um projeto tradutório específico, de que maneira podem apresentar essas diferenças culturais a um leitor ainda pouco familiarizado com elas. Em relação à influência do tradutor no aspecto pós-colonial de um texto ficcional, fica a princípio pouco claro o quanto está nas mãos do tradutor manter as características pós-coloniais de um texto. A hipótese lançada e que poderá ser verificada em uma nova pesquisa é de que as características pós-coloniais de um texto tendem a ser mantidas pelo tradutor, tendo ele pouco poder de interferir nesse sentido. No entanto, percebemos que a questão lexical se constitui como um elemento predominante da transposição cultural entre polissistemas. Finalmente, cremos que as editoras vêm apostando na publicação de obras de caráter pós-colonial no Brasil acompanhando o sucesso editorial e crítico que elas obtêm em seus países de origem.

\section{Notes}

1. "are accepted as legitimate by the dominant circles within a culture and whose conspicuous products are preserved by the community to become part of its historical heritage" (EVEN-ZOHAR, 1990, p. 15).

2. A partir de agora, ao nos referirmos ao autor, usaremos V.S. Naipaul.

3. Todas as traduções do capítulo de Tymoczko (2002) foram feitas pelos autores e serão acompanhadas de suas respectivas citações em inglês, também feitas em nota de rodapé. "The translator must decide how to handle features of the source culture (...) that are unfamiliar to the receiving audience, adapting and modifying the source text in the process" (TYMOCZKO, 2002, p. 23).

4. "Selectivity is essential to the construction of any piece of literature, particularly when the intended audience includes readers who are unfamiliar with the cultural subject" (TYMOCZKO, 2002, p. 23).

5. "Such a process of selectivity and interpretation is ideological and will inevitably invite controversy" (TYMOCZKO, 2002, p. 24).

6. "Once wealthy aristocrats - now take the form of presses and publishing houses, universities [...]" (TYMOCZKO, 2002, p. 30).

7. "Patrons determine the parameters of what is translated just as they determine parameters of what is published" (TYMOCZKO, 2002, p. 30). 
8. "[...] producing texts with large amounts of material that is opaque or unintelligible to international readers on the one hand or having large quantities of explanation and explicit information on the other hand" (Tymoczko, 2002, p. 29).

9. "In translation studies a distinction is often made between "bringing the text to the audience' and 'bringing the audience to the text"' (TYMOCZKO, 2002, p. 29).

10. "In translations the greater the prestige of the source culture and the source text, the easier it is to require that the audience come to the text" (TYMOCZKO, 2002, p. 29).

11. "The greater the international reputation of an author, the greater the demands that can be placed upon an international audience" (TYMOCZKO, 2002, p. 29).

12.É importante frisar que o romance Half a Life é um sucesso editorial, sendo traduzido para o alemão, espanhol, francês, italiano, grego, mandarim, português brasileiro e português europeu.

13. Os Mímicos (1987), Uma Casa para o Sr. Biswas (1988), O Enigma da Chegada (1994), Um Caminho no Mundo (1994), Índia (1997), Entre os Fiéis (1999), Além da Fé (1999), Meia Vida (2002), O Massagista Místico (2003), Uma Curva no Rio (2004), Sementes Mágicas (2007), Uma Casa para o Sr. Biswas (edição de bolso) (2010), A Máscara da África (2011), Uma Curva no Rio (Coleção Prêmio Nobel) (2011), Miguel Street (2012), e Num Estado Livre (2013).

14. "Studies of translations are increasingly alert to the circumstances under which books are chosen for translation and translations are published" (TYMOCZKO, 2002, p. 30).

15. (...) "the demands of international patronage will compromise the form, content and perspective of the post-colonial works themselves" (TYMOCZKO, 2002, p. $31)$.

16. Dados disponíveis em: http://www.etnicosbrasil.com.br/2012/05/normal-0-21false-false-false-pt-br-x.html. Acessado em 15 jan. 2018.

17. Dados disponíveis em: https://www.ons.gov.uk/ peoplepopulationandcommunity/culturalidentity/ethnicity/articles/ethnicityand nationalidentityinenglandandwales/2012-12-11. Acesso em 15 jan. 2018.

18. https://en.oxforddictionaries.com/

19. https://en.oxforddictionaries.com/definition/kama_sutra. Acesso em 16 fev. 2019.

20. https://michaelis.uol.com.br/

21. A Guerra da Independência de Moçambique travada contra Portugal durou de 1964 a 1974, data que houve um cessar-fogo. O reconhecimento da independência do país africano só ocorreu em 25 de junho de 1975.

22. Isa Mara Lando já traduziu além de Naipaul, Salman Rushdie e Chinua Achebe.

Referências

BHABHA, H. K. O local da cultura. Tradução de Myriam Ávila, Eliana Lourenço de Lima Reis, Gláucia Renate Gonçalves. - 2. Ed. - Belo Horizonte: Editora UFMG, 2013.

BONNICI, T. Introdução ao estudo das literaturas pós-coloniais. Mimesis, Bauru, v. 19, n. 1, p. 07-23, 1998.

COUTINHO, E. F. Literatura comparada na América Latina: ensaios. Rio de Janeiro: EdUERJ, 2003. 
EVEN-ZOHAR, I. Polysystem Studies. Poetics Today, [s/l], v. 11, n. 1, 1990, p.10-27. Disponível em: <http://www.tau.ac.il/ itamarez/works/books/ez-pss1990.pdf>. Acesso em: jan. 2018.

FERREIRA, A. B. de. Novo Aurélio Século XXI: o dicionário da língua portuguesa. Rio de Janeiro: Nova Fronteira, 1999.

HALL, S. Da diáspora: identidades e mediações culturais. Belo Horizonte: Editora UFMG, 2003.

LANDO, I. M. Entrevista concedida à autora. 30 dez. 2017.

OXFORD ADVANCED LEARNER'S DICTIONARY. Oxford: Oxford University Press, 2005.

LEFEVERE, A. Tradução, reescrita e manipulação da fama literária. Tradução de Claudia Matos Seligmann. Bauru, São Paulo: Edusc, 2007.

MASCENA, S. C. R.; LÚCIO, A. C. M.. Colonialismo e pós-colonialismo no romance A Varanda do Frangipani de Mia Couto. Cultura \& Tradução. João Pessoa, v.1, n. $1,2011$.

NAIPAUL, V. N. Half a Life. New York: Alfred A. Knopf, 2001.

NAIPAUL, V. N. Meia Vida. Tradução de Isa Mara Lando. São Paulo: Companhia das Letras, 2002.

RANDOM HOUSE WEBSTER'S UNABRIDGED DICTIONARY. New York: Random House, Inc: 1997.

SANTOS, B. de S. Do pós-moderno ao pós-colonial. E para além de um e outro. Travessias. Revista de Ciências Sociais e Humanas em Lingua Portuguesa. Coimbra. Edição dos números 6/7, p. 15-36, 2008. Disponível em: <https://estudogeral.sib. uc.pt/handle/10316/43227>. Acesso em: 31 jan. 2019.

TYMOCZKO, M. Post-colonial writing and literary translation. In: BASSNETT, Susan; HARISH, Trivedi. Post-colonial translation: theory \& practice. Taylor \& Francis e-Library. 2002. Disponível em: <http://translationindustry.ir/Uploads/ Pdf/Post-Colonial_Translation.pdf >. Acesso em: 13 jan. 2018. 